\title{
SYNDROMIC SURVEILLANCE: ETIOLOGIC STUDY OF ACUTE FEBRILE ILLNESS IN DENGUE SUSPICIOUS CASES WITH NEGATIVE SEROLOGY. BRAZIL, FEDERAL DISTRICT, 2008
}

Ailton Domicio da SILVA(1) \& Maria do Socorro Nantua EVANGELISTA(2)

\begin{abstract}
SUMMARY
With the aim of identifying the etiology of acute febrile illness in patients suspected of having dengue, yet with non reagent serum, a descriptive study was conducted with 144 people using secondary serum samples collected during convalescence. The study was conducted between January and May of 2008. All the exams were re-tested for dengue, which was confirmed in 11.8\% ( $\mathrm{n}=17$ ); the samples that remained negative for dengue $(n=127)$ were tested for rubella, with $3.9 \%(n=5)$ positive results. Among those non reactive for rubella $(\mathrm{n}=122)$, tests were made for leptospirosis and hantavirus. Positive tests for leptospirosis were $13.9 \%(\mathrm{n}=17)$ and none for hantavirus. Non reactive results (70.8\%) were considered as Indefinite Febrile Illness (IFI). Low schooling was statistically associated with dengue, rubella and leptospirosis $(\mathrm{p}=0.009)$, dyspnea was statistically associated with dengue and leptospirosis $(\mathrm{p}$ $=0.012)$, and exanthem/petechia with dengue and rubella $(\mathrm{p}=0.001)$. Among those with leptospirosis, activities in empty or vacant lots showed statistical association with the disease $(p=0.013)$. Syndromic surveillance was shown to be an important tool in the etiologic identification of IFI in the Federal District of Brazil.
\end{abstract}

KEYWORDS: Epidemiological surveillance; Syndromic surveillance; Dengue; Rubella; Leptospirosis.

\section{INTRODUCTION}

The use of syndromic surveillance in acute febrile diseases has been an important tool for detecting indefinite febrile illnesses ${ }^{31}$. Experiments putting this working model into operation were tested based on the surveillance of dengue fever with the intention of diagnosing leptospirose $\mathrm{e}^{6,22}$, during the surveillance of acute exanthematous febrile illness for identifying cases of dengue and rubella ${ }^{12}$ and during the outbreak of acute illness, when cases of dengue, leptospirosis, meningococcal disease and hantavirus were suspected ${ }^{23}$.

The nonspecific clinical manifestations of fever, headache and myalgia are common in cases of hantavirose $e^{3,11,16,20}$, rubella ${ }^{12}$, dengue fever, and leptospirosis; the prodromes of which are similar to each other and to other viral diseases. Information based on epidemiological history and specific laboratory findings ${ }^{16}$ are important for conclusive diagnosis. Thus, the use of differential diagnosis from the surveillance of acute febrile diseases is important since it contributes significantly to the elucidation of the etiology of these indefinite diseases ${ }^{3,10,20,}$.

In the Federal District, nearly $70.0 \%$ of suspected dengue fever cases are ruled out by serology, indicating that this disease is the first diagnosis hypothesis ${ }^{13}$ for health professionals.

This study used syndromic surveillance in order to identify the etiology of acute febrile diseases in serologically nonreactive individuals who were suspected cases of dengue, aiming at expanding the etiologic knowledge of these syndromes in the Federal District.

\section{METHODS}

This is a descriptive case sample developed in a specific demand population seen at the Federal District Central Public Health Laboratory (Lacen/DF) from January to May 2008, which corresponds to the rainy season. To select the sample, results of serological tests contained in the epidemiological reports generated by Lacen/DF were used.

Among the 877 eligible patients with acute febrile illness seen during the period studied, each week from eight to ten randomly sampled participants were selected, totaling 144 participants. The order of testing was determined by epidemiological characteristics of these diseases in the population of the Federal District. The sample was calculated by the formula ${ }^{17} \mathrm{n}=\mathrm{pq} / \mathrm{E}^{2}$, where " $\mathrm{p}$ " means the prevalence of the diseases in question, which was drawn from the data on rubella, leptospirosis and hantavirus infection, confirmed through the Information System for Notifiable Diseases (SINAN) from 2001 to 2006, and " $q$ " represents the percentage of people who did not present with the diseases investigated. $\left(\mathrm{E}^{2}\right)$ of $\pm 2.5 \%$ and a CI of $95 \%$ were considered. Subsequently, an interview was set up by telephone with the patient's consent, after which serological material was collected. Those patients who refused to be interviewed were excluded from the study. 


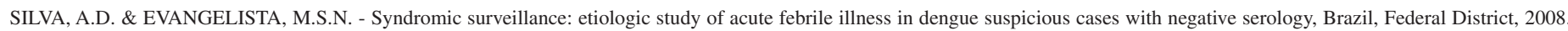
Rev. Inst. Med. Trop. Sao Paulo, 52(5): 237-42, 2010.

The samples were collected a maximum of 28 days after the onset of symptoms. All sera samples were re-tested for dengue. Samples that were not reactive for dengue were used for the detection of rubella. Tests for leptospirosis were conducted on the samples that were negative for rubella, and those that were negative for leptospirosis were processed for hantavirus. It is important to emphasize that the observed denominators were different depending on the exclusion of positive tests conducted after the confirmation of dengue and other diseases. The protocol did not include testing for co-infections.

The ELISA method was used for detection of IgM with the commercial PANBIO reagent for dengue and the MAC-ELISA (Evandro Chagas Institute) method was used for inconclusive cases. For identification of rubella IgM, Behring's commercial reagent was used, and for leptospirosis, the Bio-Manguinhos's commercial reagent was used. Tests for hantavirus used the reagent with Andes Hantavirus antigens produced by the Malbrán Institute (Buenos Aires, Argentina).

Statistical analysis applied the exact chi-square $\left(\chi^{2}\right)$ when over $20 \%$ of the expected frequencies were less than five with $\mathrm{p} \leq 0.05$ and then the frequencies and percentages were evaluated. The data were processed using Statistical Analysis Software (SAS) version 9.1.3. The study was submitted to and approved by the Brazilian Federal District Healthcare Secretary Council on Ethics in Research (Opinion No. 215/2007).

\section{RESULTS}

The etiology of $27.1 \%$ of cases (39/144) of patients with acute febrile syndrome was identified. In $11.8 \%$ (17/144) of those investigated $\left(\mathrm{CI}_{95 \%}: 6.47-17.14 \%\right)$ were diagnosed with dengue (Table 1). Rubella was confirmed in $3.9 \%$ of the patients, i.e., $5 / 127$ of the samples that were negative for dengue $\left(\mathrm{CI}_{95 \%}: 0.51-7.42 \%\right)$. The diagnosis of leptospirosis was made in $13.9 \%$ of patients, representing $17 / 122$ negative sera for rubella $\left(\mathrm{CI}_{95 \%}: 7.84-20.50 \%\right)$. No cases of hantavirus were identified. Among the samples tested, one was inconclusive for rubella and two had indeterminate results for leptospirosis. The remaining 102 serology samples $(70.8 \%)$ tested negative for the diseases investigated, and were classified as acute indefinite febrile illness (IFI).

Table 1

Reagents for the serological diagnosis of dengue, rubella and leptospirosis, Federal District, January to May 2008

\begin{tabular}{lcccc}
\hline Disease & $\mathrm{n}$ & Reagent & $\%$ & $\mathrm{CI}_{(95 \%)}$ \\
\hline Dengue & 144 & 17 & 11.8 & $6.47-17.14$ \\
Rubella & 127 & 5 & 3.9 & $0.51-7.42$ \\
Leptospirosis & 122 & 17 & 13.9 & $7.84-20.50$ \\
\hline
\end{tabular}

Regarding the results of confirmed cases by disease and sex (Table 2 ), there was a higher proportion of women in all the diseases studied, although this difference was not statistically significant $(p=0.956)$. The age group of 20 years old and over was the most represented in all the febrile diseases, without statistical significance $(\mathrm{p}=0.185)$. With respect to race/color, among the confirmed dengue cases, $47.1 \%$ were white, $29.4 \%$ black, and $23.5 \%$ were mulatto. Considering the patients identified with rubella according to race or color, $40.0 \%$ were white,
$40 \%$ mulatto, and $20.0 \%$ Asian. In patients diagnosed with leptospirosis, $64.7 \%$ reported being mulatto. In the IFI group, $51.0 \%$ of the respondents considered themselves to be mulatto. In the comparison of cases relating race/color of patients with dengue, rubella and leptospirosis, a statistically significant difference $(\mathrm{p}=0.035)$ was found.

With regard to educational level (Table 2), 62.5\% of those with one to three years of education were affected by dengue and $25.0 \%$ with leptospirosis. IFI was more present in the groups with 4-7, 8-11, and 12 years or more of education, representing $75.8 \%, 74.3 \%$ and $77.8 \%$ respectively. When comparing the association between years of education and the profile of febrile illness, there was statistical difference $(p=0.009)$.

In evaluating the clinical manifestations presented by patients with dengue, $100 \%$ of the cases reported myalgia, $94.1 \%$ headache and exhaustion, $82.3 \%$ retro-orbital pain, and $82.2 \%$, arthralgia and inappetence. As noted among the clinical cases of rubella, $100.0 \%$ of those investigated reported headache and exhaustion, while $80.0 \%$ were noted in each of the following categories: myalgia, arthralgia, inappetence, exanthem/petechia, and dyspnea. In the group of patients diagnosed with leptospirosis, $94.1 \%$ had headache and myalgia, and $82.2 \%$, exhaustion, retro-orbital pain, and arthralgia. Among the IFI group, the most frequent symptoms included myalgia $(98.0 \%)$, headache $(97.0 \%)$, exhaustion $(95.1 \%)$, and arthralgia (82.3\%). In the comparison of dyspnea in dengue and leptospirosis cases $(\mathrm{p}=0.012)$ and the findings of exanthem/petechia in cases of dengue and rubella $(\mathrm{p}=0.000)$ show statistical differences.

When considering infection with leptospira and occupational exposure of patients in this sample (Table 3 ), $41.7 \%$ of patients performed activities in vacant lots, with statistical significance $(p=0.013)$. The remaining patients diagnosed with leptospirosis had other exposures, such as breeding animals $(p=0.289)$, contact with rats $(p=0.534)$, grease traps $(\mathrm{p}=0.705)$, water tanks and septic tanks $(\mathrm{p}=1.000)$ each, trash/debris $(\mathrm{p}=0.417)$, water/mud $(\mathrm{p}=0.258)$, and rivers/streams $(\mathrm{p}=$ $0.4170)$, without statistical significance.

In regards to the temporal distribution of dengue fever by month of onset of symptoms, $41.7 \%$ of infections occurred in January, 29.4\% in February, $11.8 \%$ in both March and in April, and 5.9\% in May. In January, $60.0 \%$ of patients were affected by rubella and the remaining cases $(20.0 \%)$ were recorded between February and April. Leptospirosis comprised $23.5 \%$ of patients between January and February, $35.3 \%$ in March, $11.8 \%$ in April, and 5.9\% in May. In the IFI group, the onset of symptoms was present in $14.7 \%, 19.6 \%, 25.5 \%, 22.5 \%$ and $17.6 \%$ in January, February, March, April, and May, respectively (Fig. 1).

\section{DISCUSSION}

The proportion of positive dengue, leptospirosis and rubella found in this study was $27.1 \%$ among cases of acute febrile illness in the Federal District. A similar study conducted in Venezuela in 1998 established the etiology of dengue fever, rubella, Epstein-Barr virus, and cytomegalovirus in $77.9 \%$ of cases $^{12}$. In Jaen, Peru, a study carried out between 2004 and 2005 identified $65.4 \%$ of diseases, including malaria, leptospirosis, dengue, Rickettsia and Bartonelosis ${ }^{31}$. These differences in the proportions observed in the diagnostic confirmation between the Federal District study and the others are probably due to the period of observation, as this paper only addressed the first five months of the 


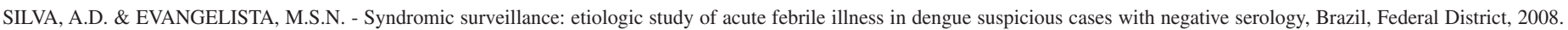
Rev. Inst. Med. Trop. Sao Paulo, 52(5): 237-42, 2010.

Table 2

Reagents for the serological diagnosis of dengue, rubella and leptospirosis, Federal District, January to May 2008.

\begin{tabular}{|c|c|c|c|c|}
\hline Variables & $\begin{array}{c}\text { Dengue } \\
\mathrm{n}(\%)\end{array}$ & $\begin{array}{c}\text { Rubella } \\
\mathrm{n}(\%)\end{array}$ & $\begin{array}{c}\text { Leptospirosis } \\
\mathrm{n}(\%)\end{array}$ & $\begin{array}{c}\text { IFI } \\
\mathrm{n}(\%)\end{array}$ \\
\hline \multicolumn{5}{|l|}{$\operatorname{Sex}(p=0.956)$} \\
\hline Female & $9(52.9)$ & $3(60.0)$ & $10(58.8)$ & $62(60.8)$ \\
\hline Male & $8(47.1)$ & $2(40.0)$ & $7(41.2)$ & $40(39.2)$ \\
\hline \multicolumn{5}{|l|}{ Age range $(\mathrm{p}=0.185)$} \\
\hline $10-19$ & - & - & $3(17.6)$ & $18(17.6)$ \\
\hline $20-29$ & $2(11.8)$ & $4(80.0)$ & $5(29.5)$ & $27(26.5)$ \\
\hline $30-39$ & $6(35.3)$ & - & $4(23.5)$ & $22(21.6)$ \\
\hline $40-49$ & $4(23.5)$ & $1(20.0)$ & $3(17.6)$ & $18(17.6)$ \\
\hline 50 and over & $5(29.4)$ & - & $2(11.8)$ & $17(16.7)$ \\
\hline \multicolumn{5}{|c|}{ Race/skin color $(p=0.035)$} \\
\hline White & $8(47.1)$ & $2(40.0)$ & $5(29.4)$ & $31(30.4)$ \\
\hline Black & $5(29.4)$ & - & $1(5.9)$ & $18(17.6)$ \\
\hline Asian & - & $1(20.0)$ & - & $1(1.0)$ \\
\hline Mullato & $4(23.5)$ & $2(40.0)$ & $11(64.7)$ & $52(51.0)$ \\
\hline \multicolumn{5}{|c|}{ Schooling $*(p=0.009)$} \\
\hline None & - & - & - & $3(100.0)$ \\
\hline $1-3$ years & $5(62.5)$ & - & $2(25.0)$ & $1(12.5)$ \\
\hline 4-7 years & $4(12.1)$ & - & $4(12.1)$ & $25(75.8)$ \\
\hline $8-11$ years & $4(5.7)$ & $4(5.7)$ & $10(14.3)$ & $52(74.3)$ \\
\hline 12 years or more & $4(14.8)$ & $1(3.7)$ & $1(3.7)$ & $21(77.8)$ \\
\hline
\end{tabular}

p-value for exact $\chi^{2}$ test; * Years of schooling.

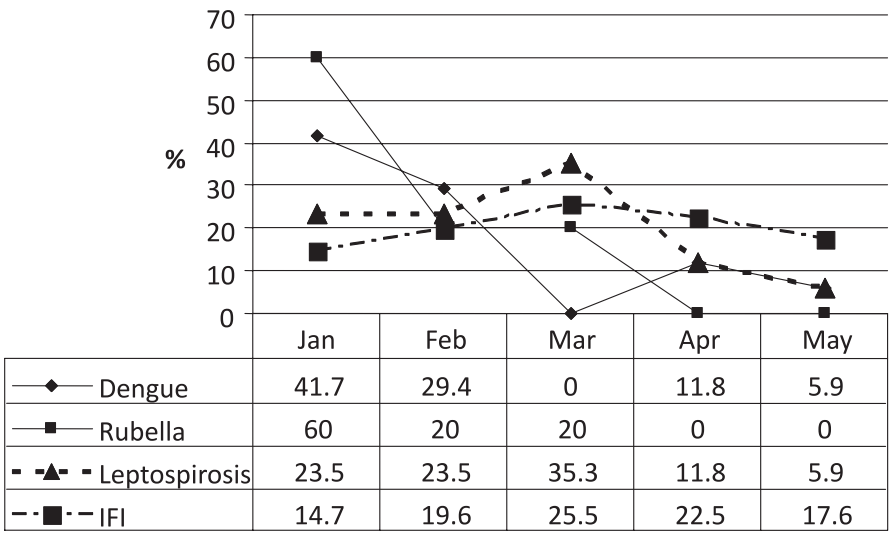

Fig. 1 - Percentage of positive reactions for dengue, rubella, leptospirosis and IFI according to the month of symptom onset, Federal District, 2008.

year, while the other studies gathered data during a longer period of observation.

Confirmation of dengue accounted for $11.8 \%$ of all the cases investigated. A survey from patients suspected of having leptospirosis ${ }^{13}$ in Barbados in 1995, 1996, and 1997, identified 44.0\%, 33.0\%, and $42.0 \%$, respectively. In Vietnam, in 2001, the percentage of dengue diagnosis identification was $33.4 \%$ during an investigation of acute indefinite febrile illness ${ }^{19}$. Finally, it is worth noting that the findings mentioned above showed percentages that were higher than those values observed in the Federal District; however, they initiated their studies to investigate diseases other than dengue and extended them for longer periods of observation.

The confirmed diagnosis of rubella in this sample was $3.9 \%$, lower than the percentage found in Zulia, Venezuela (1998) and in Niteroi, Rio de Janeiro, Brazil (1994 to 1998), from exanthematic diseases, with observed frequencies of $38.2 \%$ and $21.0 \%$ for rubella, respectively ${ }^{12,15}$. Another survey of suspected dengue cases in Yucatan, Mexico (1988 to 2001) as described by BUSTOS et al. ${ }^{7}$ showed a detection of $10.0 \%$ of subjects with rubella. In Venezuela, VALERO \& MALDONADO ${ }^{32}$ also found $1.2 \%$ of rubella from the presumptive diagnosis of dengue in the period 1998 to 2001. It should be emphasized that in 2007 there was a marked increase of the rubella virus in some Brazilian municipalities ${ }^{5}$, the consequences of which were felt in the Federal District by the increased vaccination of high risk groups. Possibly, this fact accounts for the low proportion of positive results found, reflecting the end of the rubella outbreak in the Federal District. 
SILVA, A.D. \& EVANGELISTA, M.S.N. - Syndromic surveillance: etiologic study of acute febrile illness in dengue suspicious cases with negative serology, Brazil, Federal District, 2008. Rev. Inst. Med. Trop. Sao Paulo, 52(5): 237-42, 2010.

Table 3

Types of exposure among patients with leptospirosis, Federal District, January to May 2008

\begin{tabular}{|c|c|c|c|c|c|}
\hline \multirow[t]{3}{*}{ Exposure } & \multicolumn{4}{|c|}{ Leptospirosis } & \multirow[t]{3}{*}{$\mathrm{P}$} \\
\hline & \multicolumn{2}{|c|}{ No } & \multicolumn{2}{|c|}{ Yes } & \\
\hline & $\mathrm{n}$ & $\%$ & $\mathrm{n}$ & $\%$ & \\
\hline Breeding animals & & & & & 0.289 \\
\hline Yes & 39 & 81.2 & 9 & 18.7 & \\
\hline No & 64 & 88.9 & 8 & 11.1 & \\
\hline Contact with rats & & & & & 0.534 \\
\hline Yes & 19 & 90.5 & 2 & 9.5 & \\
\hline No & 82 & 84.5 & 15 & 15.5 & \\
\hline Grease traps & & & & & 0.705 \\
\hline Yes & 10 & 90.9 & 1 & 9.1 & \\
\hline No & 93 & 85.3 & 16 & 14.7 & \\
\hline Water tanks & & & & & 1.000 \\
\hline Yes & 2 & 100 & - & 0.0 & \\
\hline No & 101 & 85.6 & 17 & 14.4 & \\
\hline Septic tanks & & & & & 1.000 \\
\hline Yes & 2 & 100 & - & 0.0 & \\
\hline No & 101 & 85.6 & 17 & 14.4 & \\
\hline Vacant lots & & & & & 0.013 \\
\hline Yes & 7 & 58.3 & 5 & 41.7 & \\
\hline No & 96 & 88.9 & 12 & 11.1 & \\
\hline Trash/debris & & & & & 0.417 \\
\hline Yes & 11 & 78.6 & 3 & 21.4 & \\
\hline No & 92 & 86.8 & 14 & 13.2 & \\
\hline Water/mud & & & & & 0.258 \\
\hline Yes & 28 & 80 & 7 & 20.0 & \\
\hline No & 75 & 88.2 & 10 & 11.8 & \\
\hline Rivers/streams & & & & & 0.417 \\
\hline Yes & 11 & 78.6 & 3 & 21.4 & \\
\hline No & 92 & 86.8 & 14 & 13.2 & \\
\hline
\end{tabular}

p-value for exact $\chi^{2}$ test.

Diagnostic confirmation of leptospirosis from suspected dengue cases with nonreactive serology showed a positive rate of $13.9 \%$. Studies using syndromic surveillance from reports of suspected dengue, such as the LIBRATY et al. ${ }^{14}$ study in the city of Kamphaeng Phet, Thailand from 1994 to 1999, found an incidence of 19.0\%. In Puerto Rico (1996), $27.0 \%$ of leptospirosis ${ }^{22}$ cases were detected after discarding dengue suspect cases. Mato Grosso do Sul, Brazil, (2000 to 2001) showed a rate of $15.9 \%{ }^{26}$ from suspected dengue and viral hepatitis cases. In comparison with other studies cited, the similarities are evident, except in relation to the survey conducted in Puerto Rico. In the Federal
District, the high incidence of leptospirosis became evident as a result of the anicteric hepatitis outbreak among patients who sought the health care system. It should be noted that the study also allowed clarification of the diagnosis, especially when the discarded cases of dengue were submitted to syndromic surveillance, confirming the studies mentioned previously ${ }^{13,14,18,22,26}$.

On the other hand, labor performed in vacant lots showed statistical significance. The literature has pointed to epidemiological data on the transmission of leptospira to people who are exposed to water that has been contaminated by rat urine, especially during the rainy season ${ }^{2,28}$, during occupational and recreational activities in rainwater and runoff $\mathrm{f}^{24,27}$, not to mention a close relationship with the socio-economic conditions of the population ${ }^{1,26}$. Based on the literature, it seems permissible to think that the transmission of leptospirosis in the survey area was related to exposures at home and at work, since the hydrographic formation does not favor basin flooding and basic sanitation reaches almost the entire urban Federal District population.

The relationship between self-reported race/color and illness/disease showed a statistically significant difference for dengue and whites and blacks, rubella and whites, and leptospirosis and mulattos. The risk of developing dengue hemorrhagic fever, in a study by TORRES ${ }^{30}$, demonstrates that a higher incidence occurred with whites as compared to blacks. According to data from 2007 to 2008 in Brazil, nearly 60.0\% of patients diagnosed positive for rubella and leptospirosis were white ${ }^{4}$, a result which coincides with our findings for rubella, but differs for leptospirosis.

A statistically significant association was observed among those interviewed with 1-3 years of education and dengue and leptospirosis, as well as among those who had more years of education and rubella and IFI. VASCONCELOS et al. ${ }^{33}$ found no correlation between dengue and schooling in Ceara, Brazil in 1994. In Salvador, Bahia, Brazil, in 1998, it was found that the higher the education level, the lower the incidence of dengue ${ }^{29}$; an association between lower education and leptospirosis was also observed ${ }^{9}$. In summary, research suggests some uncertainty as to the association of schooling with dengue.

The manifestations of the main signs and symptoms present in the definition of suspected dengue "cases" were present in more than $80.0 \%$ of the diseases diagnosed in this study, except retro-orbital pain with the occurrence of rubella. Dyspnea was statistically associated with dengue and leptospirosis, while exanthem/petechia was associated with dengue and rubella. Some studies in the investigation of dengue, leptospirosis, and exanthem diseases attested to clinical manifestations of fever, myalgia, headache, and exhaustion similar to the sample in the present study, while in other studies, the percentages were below $80.0 \%{ }^{8,10}$. This evidence reinforces the difficulty of purely clinical differentiation in diagnostic elucidation ${ }^{10,11,14}$ of acute febrile disease and the relevance of syndromic surveillance to identify these etiologies.

When analyzing the question of the seasonality of acute febrile diseases, the highest occurrence of dengue fever was observed in the first quarter of the year, with $79.5 \%$ of the cases, an epidemiological pattern similar to that found by SMITH et al. ${ }^{25}$ in Brazil. The seasonal observation of cases of leptospirosis in the Federal District resembles the historical dataset (1967 to 1977) collected in San Paulo ${ }^{21}$, which coincides 


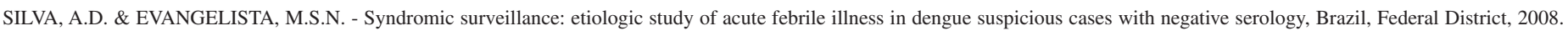
Rev. Inst. Med. Trop. Sao Paulo, 52(5): 237-42, 2010.

with findings from the literature that identified a greater transmission of dengue and leptospirosis during the rainy season ${ }^{1}$.

\section{CONCLUSION}

This study highlighted an increase in the diagnosis of dengue, rubella, and leptospirosis in unconfirmed cases of dengue, highlighting the importance of the syndromic approach towards acute febrile diseases resulting from the expansion of surveillance. Moreover, this strategy reduced the underreporting of acute febrile diseases in the Federal District, allowing for a better understanding of the epidemiology of such diseases, in addition to promoting more effective control measures.

\section{FINAL THOUGHTS}

To strengthen the surveillance of acute febrile syndromes through the surveillance of dengue, the study results indicate the following needs:

1. For patients suspected of dengue and who fit the case definition, epidemiological research should consider the possibility of risk exposure to leptospirosis and/or recent contact with exanthematic cases, thus widening the scope of the investigative framework.

2. During the investigation of exanthematic cases, consider the possibility of dengue.

3. When confronted with a negative serology result for dengue, consider all the clinical manifestations presented and evaluate the possibility of a new serology, since the initial serology may not have presented titers of detectable antibodies.

4. Develop a protocol for acute febrile syndromes, focusing on care, and epidemiological and laboratory surveillance.

5. Train human resources in terms of health services, epidemiological, and laboratory surveillance focusing on acute febrile syndromes.

\section{RESUMO}

\section{Vigilância sindrômica: estudo etiológico de doenças febris agudas a partir dos casos suspeitos de dengue com sorologia não reagente. Distrito Federal, Brasil, 2008}

Com o objetivo de identificar a etiologia de doenças febris agudas, em suspeitos de dengue com sorologia não reagente, realizou-se estudo descritivo com 144 pessoas utilizando amostras de soro coletados na convalescença, entre janeiro e março de 2008. Todos os exames foram re-testados para dengue, sendo as amostras negativas, processadas para rubéola $(\mathrm{n}=127)$. Dentre as não reagentes para rubéola, submeteuse ao teste para leptospirose $(n=122)$, e em se permanecendo sem diagnóstico, testou-se para hantavirose. Confirmou-se dengue em $11,8 \%(\mathrm{n}=17)$, rubéola em 3,9\% $(\mathrm{n}=5)$ e leptospirose em $13,9 \%$ $(\mathrm{n}=17)$. Os resultados não reagentes foram considerados como doença febril aguda indiferenciada (DFI) em $70.8 \%$ dos casos. Verificou-se associação estatística em baixa escolaridade nos casos de dengue, rubéola e leptospirose $(\mathrm{p}=0,009)$, assim como dispnéia para dengue e leptospirose $(\mathrm{p}=0,012)$, e exantema/petéquias para dengue e rubéola ( $\mathrm{p}$ $=0,001)$. Dentre os doentes com leptospirose, as atividades em terreno baldio mostraram-se com diferença estatística significante $(p=0,013)$. A vigilância sindrômica demonstrou-se como importante ferramenta na identificação de doenças febris agudas no Distrito Federal.

\section{REFERENCES}

1. Barcellos C, Lammerhirt C B, Almeida MAB, Santos E. Distribuição espacial da leptospirose no rio Grande do Sul, Brazil: recuperando a ecologia dos estudos ecológicos. Cad. Saúde Pública. 2003;19:1283-99.

2. Barcellos C, Sabroza PC. The place behind the case: leptospirosis risks and associate environmental conditions in a flood-related outbreak in Rio de Janeiro. Cad. Saúde Pública. 2001;17 (Suppl):59-67.

3. Baum S. Infecciones por micoplasma. In: Wyngaarden JB, Smith LH, Bennett, JC, editors Cecil Tratado de Medicina Interna. 19ª ed. Rio de Janeiro: Guanabara Koogan; 1993. v. 2, p. 1880-3. Apud: Hinojosa PM, Villagra CE, Mora, RJ, Maier L. Identificación de otros agentes infecciosos en casos sospechosos de síndrome cardiopulmonar por hantavírus. Rev Méd Chile. 2006; 134:332-8.

4. Brasil. Ministério da Saúde. Sistema de Informação de Agravos de Notificação. Available from: http://dtr2004.saude.gov.br/sinanweb/novo/ [Accessed on March 12, 2009]

5. Brasil. Ministério da Saúde. Surto de Rubela no Brasil. Atualização. Available from: http:// portal.saude.gov.br/portal/arquivos/pdf/alerta_rubeola_21_12_2007.pdf. [Accessed on March 12, 2009].

6. Bruce MG, Sanders EJ, Leake JAD, Zaidel O, Bragg SL, Aye T, et al. Leptospirosis among patients presenting with dengue-like illness in Porto Rico. Acta Trop. 2005;96:36-46.

7. Bustos J, Hamdan A, Loroño MA, Monteiro MT, Gómez B. Serologically proven acute rubella infection in patient with clinical diagnosis of dengue. Epidemiol Infect. 1990;104:297-302.

8. Casali CG, Pereira MR, Santos LM, Passos MN, Fortes BP, Ortiz Valencia LI, et al. A epidemia de dengue/dengue hemorrágica no Município do Rio de Janeiro, 2001/2002. Rev Soc Bras Med Trop. 2004;37:296-9.

9. Dias JP, Teixeira MG, Costa MC, Mendes CM, Guimarães P, Reis MG, et al. Factors associated with Leptospira sp infection in a large urban center in the northeastern in Brazil. Rev Soc Bras Med Trop. 2007;40:499-504.

10. Díaz FA, Matínez RA, Villar LA. Critérios clínicos para el diagnóstico del dengue en los primeros dias de enfermedad. Biomédica. 2006;26:22-30.

11. Flannery B, Pereira MM, Velloso LF, Carvalho CC, De Codes LG, Orrico GS, et al Referral pattern of leptospirosis cases during a large urban epidemic of dengue. Am J Trop Med Hyg. 2001;65:657-63.

12. León LC, Estévez J, Castillo FM, Callejas D, Echevarría JM. Diagnóstico etiológico de pacientes con exantemas o cuadros febriles atendidos en 1998. Estado Zulia, Venezuela. Rev Méd Chile. 2004;132:1078-84

13. Levett PN, Branch SL, Edwards CN. Detection of dengue infection in patients investigated for leptospirosis in Barbados. Am J Trop Med Hyg. 2000;62:112-4

14. Libraty DH, Myint KS, Murray CK, Gibbons RV, Mammen MP, Endy TP, et al. A comparative study of leptospirosis and dengue in Thai children. Plos Negl Trop Dis. 2007; 1:e111.

15. Oliveira SA, Camacho LAB, Bettini LR, Fernandes DG, Gouvea NA, Barros RA, et al. Manifestações articulares nas viroses exantemáticas. Rev Soc Bras Med Trop. 1999;32:125-30.

16. Organización Panamericana de La Salud. Hantavírus en las Américas, guia para el diagnóstico, el tratamiento, la prevención y el control. Washington: OPS; 1999. (Caderno Técnico $\mathrm{N}^{\circ} 47$ ).

17. Pereira MG. Epidemiologia: teoria e prática. Rio de Janeiro: Guanabara Koogan; 2005

18. Peru. Ministerio de la Salud. Perfil etiológico del síndrome febril icterohemorrágico agudo y síndrome febril ictérico agudo en Los Valles del Apurímac, Quillabamba, Chanchamayo y alto Huallaga, Peru, 1999-2000. Rev Peru Med Exp Salud Publica. 2003;30:132-7. 
SILVA, A.D. \& EVANGELISTA, M.S.N. - Syndromic surveillance: etiologic study of acute febrile illness in dengue suspicious cases with negative serology, Brazil, Federal District, 2008. Rev. Inst. Med. Trop. Sao Paulo, 52(5): 237-42, 2010.

19. Phuong HL, de Vries PJ, Nga TTT, Giao PT, Hung le Q, Binh TQ, et al. Dengue as a cause of acute undifferentiated fever in Vietnam. BMC Infect Dis. 2006;6:123.

20. Raboni SM, Levis S, Rosa EST, Bisordi I, Delfraro A, Lemos E, et al. Hantavirus infection in Brazil: development and evaluation of an enzyme immunoassay and immunoblotting based on $\mathrm{N}$ recombinant protein. Diagn Microbiol Infect Dis. 2007;58:89-97.

21. Romero EC, Bernardo CCM, Yasuda PH. Human leptospirosis: a twenty-nine-year serological study in São Paulo, Brazil. Rev Inst Med Trop Sao Paulo. 2003;45:245-8.

22. Sanders EJ, Rigau-Pérez JG, Smits HL, Deseda CC, Vorndam VA, Aye T, et al. Increase of leptospirosis in dengue-negative patients after a hurricane in Puerto Rico in 1966. Am J Trop Med Hyg. 1999;61:399-404.

23. Santos ED, Hironi ST, Sabioni CH, Ascenzi ED, Buzzar MR, Alves MJCP, et al. Surto de rickettsioses do grupo febre maculosa entre pescadores, Paulínia, São Paulo. Apud: Brigina K. Os casos que não se confirmaram como dengue durante a epidemia de dengue no Município de Campinas/SP. [Tese] Campinas: Universidade de Campinas; 2002 .

24. Sehgal SC. Epidemiological patterns of leptospirosis. Ind J Med Microbiol. 2006;24:310-1.

25. Siqueira Jr JB, Martelli CMT, Coelho GE, Simplício ACR, Hatch DL. Dengue and dengue hemorrhagic fever in Brazil, 1981-2002. Emerg Infect Dis. 2005;11:48-53.

26. Souza AI, Nogueira JMR, Pereira MM. Anticorpos anti-leptospira em pacientes de Mato Grosso do Sul com suspeita clínica de dengue ou hepatite viral. Rev Soc Bras Med Trop. 2007;40:431-5.
27. Swapna RN, Tuteja U, Nair L, Sudarsana J. Seroprevalence of leptospirosis in high risk groups in Calicut, North Kerala, India. Ind J Med Microbiol. 2006;24:349-52.

28. Tassinari WS, Pellegrini DCP, Sabroza PC, Carvalho MS. Distribuição espacial da leptospirose no Município do Rio de Janeiro, Brasil, ao longo dos anos de 1996-1999. Cad Saúde Pública. 2004;20:1721-9.

29. Teixeira, MG, Barreto ML, Costa MCN, Ferreira LDA, Vasconcelos P. Dinâmica de circulação do vírus da dengue em uma área metropolitana do Brasil. Epidemiol Serv Saúde. 2003;12:87-97.

30. Torrez, EM. Dengue. Rio de Janeiro: Editora Fiocruz; 2005.

31. Troyes LR, Fuentes LT, Troyes MR, Canelo LD, Garcia MM, Anaya ER, et al. Etiologia del síndrome febril agudo en La Provincia de Jaén, Peru 2004-2005. Rev Peru Med Exp Salud Publica. 2006;23:165-74

32. Valero N, Maldonado M. Importancia del diagnóstico confirmatorio en enfermidades exantemáticas de etiologia viral en el Estado de Zulia, Venezuela: una revisón de problema. Invest Clin. 2006;47:301-10.

33. Vasconcelos PFC, Lima JWO, Rosa APAT, Timbó MJ, Rosa EST, Lima HR, et al. Epidemia de dengue em Fortaleza, Ceará: inquérito soro-epidemiológico aleatório 1998. Rev. Saúde Pública. 1998;32:447-54

Received: 21 April 2010

Accepted: 27 August 2010 